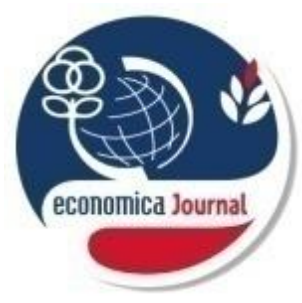

ISSN : $2302-1590$

E-ISSN: $2460-190 X$

\title{
ECONOMICA
}

Jurnal Program Studi Pendidikan Ekonomi

STKIP PGRI Sumatera Barat Vol.9 No.2 (172 - 181)

\section{MONETARY VS FISCAL POLICY, WHICH IS MORE EFFECTIVE? CASE STUDIES OF ASEAN}

\author{
By \\ M. Afdal. Samsuddin'), Nisha Selvia ${ }^{2)}$ \\ ${ }^{1)}$ Doctoral Study Program of Economics, Faculty of Economics, Andalas University \\ Email: afdalm7@gmail.com \\ ${ }^{2)}$ Economic Department, STKIP PGRI Sumatera Barat \\ Email: nishaselvia@gmail.com \\ Submitted: 2020.12.10 Reviewed: 2021.04.08 Accepted:2021.04.29 \\ https://doi.org/10.22202/economica.2021.v9.i2.4562
}

\begin{abstract}
Purpose of this study is to analyze the effectiveness of monetary and fiscal policies on economic growth in ASEAN5 (Indonesia, Malaysia, Philippines, Thailand, and Vietnam) from 1998 to 2019. Monetary policy is measured from inflation, fiscal policy is measured from government spending, and economic growth is measured from GDP's growth based on constant prices 2010. Data analysis techniques use Vector Auto Regressive (VAR), Impulse Response Function (IRF), and Variance Decomposition (VD). The results show that monetary policy is much more effective than fiscal policy in Asean-5. Fiscal policy is considered ineffective in this study, it does not mean that fiscal policy in ASEAN-5 has not had any influence on economic growth, but the point is, the role of fiscal policy during the study period is less than monetary policy. Given the irregular allocation of budget funds and non-productive expenditures by the fiscal authorities, the ineffectiveness of fiscal policy is not surprising. In addition, in an unstable market environment, the implementation of fiscal policy is highly determined and controlled by political forces.
\end{abstract}

Jel Classification:

$\mathrm{N1;O23;O4}$

Keyword: Monetary, Fiscal, Economic Growth 


\section{INTRODUCTION}

Increasing the production of goods and services that we usually call GDP, as well as the welfare of the people, is the final goal of macroeconomics that a country wants to achieve. To achieve this goal, it is necessary to carry out policies that are right on target, so that the economy grows rapidly. These policies are fiscal and monetary policies.

In recent years, the effectiveness of fiscal and monetary policy in the economy has been a source of debate among economists. On the one hand, empirical studies using structural models show that fiscal policy has a greater impact on the economy. On the other hand, empirical studies using a monetaryist model show that monetary policy has a greater influence (Fatima \& Iqbal, 2003). We know that fiscal and monetary policies are always in opposite directions in influencing macroeconomics. For that, we need to find out which policies are the most effective in influencing the economy. The effectiveness of this policy, is not just a coordination or interaction between policies, but how these policies are able to overcome various challenges and economic phenomena that occur.

The theory that initiated the theory of the effectiveness of monetary and fiscal policy is the theory of classical and Keynesian theory. These two theories have different views on the policies taken in the economy. Classical theory developed by the Monetarists (Neo-classical) emphasizes the use of monetary policy in overcoming economic problems. This opinion is based on the premise that the effect of monetary policy on aggregate demand is direct. Additional cash will not necessarily be purchased in securities, but will be spent directly in the form of goods. Fiscal policy in this case is considered less effective in influencing the economy given the crowding out effect in the policy. Meanwhile, according to the Keynesian theory, it states that monetary policy has an impact on the economy through several channels (transmission mechanisms). These routes tend to cause the effects of monetary policy to be uncertain. Keynes put more emphasis on the use of fiscal policy in the economy. This is based on his opinion that, firstly, the elasticity of money demand against the interest rate is very small (extreem zero) so that the IS curve is upright. Expansive fiscal policy will shift the IS curve to the right so that output increases. Meanwhile, monetary expansion with the addition of the money supply on the vertical IS curve will not affect output. This shows that fiscal policy will be more effective than monetary policy (Romer, 2011).

This research refers to research by (Dahalan \& Jayaraman, 2006), which examines monetary and fiscal policy in Fiji. Found that in the long run fiscal policy, which is represented by government spending, has a greater impact than monetary policy on gross domestic product. Meanwhile, in the short term, only fiscal policy has an influence on GDP. The results of his research support the Keynesian theory where fiscal policy is an important variable on maintaining macroeconomic stability. Originality in this study is the researcher who examines five Asean countries, namely Indonesia, Malaysia, Thailand, the Philippines, and Vietnam.

Research refers by (Fatima \& Iqbal, 2003), examined the effectiveness of monetary and fiscal policies in econometric studies in five Asian countries (Pakistan, India, Thailand, Indonesia, and Malaysia). Found that there is a strong reciprocal relationship between fiscal policy and economic growth and for monetary policy there is a causal relationship with economic growth in Thailand. Research from (Tan, et al., 2020), which examines the impact of monetary and fiscal policy on economic growth in Malaysia, Singapore, and Thailand. Found the monetary policy is more effective in Malaysia and Singapore, while fiscal policy was effective in Thailand. Research from (Arestis \& Sawyer, 2004), which reviews the 
effectiveness of monetary and fiscal policy. It concludes that, the monetary policy is powerless, while fiscal policy (under certain conditions) remains a powerful tool in maintaining macroeconomic stability. Research from (Jawadi, Mallick, \& Sousa, 2015), which examined fiscal and monetary policy in BRICs, which found that monetary contraction causes, a decrease in real economic activity and tightens liquidity market conditions, while government spending shocks have a strong Keynesian effect, meaning fiscal policy have a greater influence on the economy.

Research from (Rahman, 2009), examines the effectiveness of monetary and fiscal policy on output growth in Bangladesh. Found that, only monetary policy has a significant positive impact on real output growth in Bangladesh. Research from (Takyi, 2017), which examines the effect of monetary and fiscal policy on economic growth in Ghana. The results found that, in comparison, monetary policy is more effective in Ghana than fiscal policy, both long and short term. Research from (Ali, Irum, \& Ali, 2008), examines the effectiveness of fiscal and monetary policies for economic growth in South Asian countries. The results found that, monetary policy is more effective than fiscal policy for economic growth in South Asian countries. Research from (Idris, 2019), investigates the impact of monetary and fiscal policy on economic growth in a small open economy in Nigeria. The results found that, monetary policy is much more effective than fiscal policy in the study's period. Research from (Ajisafe \& Folorunso, 2002), which examines the effectiveness of fiscal and monetary policies on macroenomic management in Nigeria. The results found that, monetary policy has a greater impact on economic activity in Nigeria than fiscal policy. Research from (Abdullahi \& Omeiza, 2019), which examines the impact of monetary and fiscal policy on economic growth in Nigeria, the results foind that, the money supply contributes the most significantly to GDP predictions in Nigeria than tax revenue generated. This means that monetary policy has a greater influence than fiscal policy.

This study refers to research from (Musa, Asare, \& Gulumbe, 2013), which examines the effectiveness of the interaction between, monetary and fiscal policy on output growth in Nigeria. Found that, monetary and fiscal policies have a greater impact on real GDP in Nigeria. Monetary and fiscal optimization, have an impact on macroeconomic stabilization, which requires optimal interactions on order to achieve the goals expected by policy makers. Research from (Tadesse \& Melaku, 2019), examines the impact of monetary and fiscal policy on economic growth in Ethiopia. The results found that, monetary and fiscal policy have the same significant and positive effect on economic growth in Ethiopia, but fiscal policy is more effective than monetary policy on influencing Real GDP in the long run. However, in the short term, fiscal policy is effective whereas monetary policy proxies by the money supply are not effective in influencing output growth in Ethiopia.

Research from (Adegoriola, 2018), which examines the effectiveness of monetary and fiscal policy instruments on economic stabilization in Nigeria. The results found that, there is a long-run equilibrium relationship between monetary and fiscal variables and economic growth in Nigeria. This is confirmed by a positive relationship between the money supply, government spending and income , while interest rates and budget deficit have a negative relationship with economic growth.

\section{METHODS}

This research located in five Asean countries, that is, Indonesia, Malaysia, Philippines, Thailand and Vietnam. The data in this study started from 1998 - 2019. These data were obtained from the World Bank in the 
form of economic growth based on the growth of GDP based constant price 2010 which is measured in percent, inflation based on the consumer price index in percent, and government spending which is calculated from the percentage of expenditure government consumption to GDP.

The analysis method used in this research is Vector Autoregression (VAR). A policy is said to be effective, if the contribution of policy shocks to an endogenous variable has the greatest role (in percent) compared to other policies (Satrianto, 2017). The model of the effectiveness of fiscal and monetary policy on economic growth with the VAR model is shown as follows:

$E G=\alpha_{i t}+\sum_{i=1}^{n} \beta_{1 i} E G+\sum_{i=1}^{n} \gamma_{i t} I N F_{t-1}+$ $\sum_{i=1}^{n} \delta_{1 i} G_{i=1}+\varepsilon_{1 t}$
$I N V=\quad \alpha_{i t}+\sum_{i=1}^{n} \beta_{1 i}+\sum_{i=1}^{n} \gamma_{i t} I N F_{t-1}+$ $\sum_{i=1}^{n} \delta_{1 i} G_{i=1}+\varepsilon_{2 t}$

$G=\alpha_{i t}+\sum_{i=1}^{n} \beta_{1 i} E G+\sum_{i=1}^{n} \gamma_{i t} I N F_{t-1}+$ $\sum_{i=1}^{n} \delta_{1 i} G_{i=1}+\varepsilon_{3 t}$

\section{RESULTS AND DISCUSSION}

\section{a. Stationary Test}

The first step taken to analyze the effectiveness of monetary and fiscal policy on economic growth is to test stationary. From the stationary test conducted, the variables of economic growth, monetary policy, and fiscal turned out to be stationary at the level stage, with a probability of $<0.05$, therefore it is no longer needed at the 1 st difference or $2 \mathrm{nd}$ difference stages. This condition can be seen in table 1.

Table 1. Stationary Test Results

\begin{tabular}{llll}
\hline No. & Variabels & Probability (Level) & Conclusion \\
\hline 1 & Economic Growth (EG) & 0.0000 & Stationer \\
2 & Monetary Policy (INV) & 0.0000 & Stationer \\
3 & Fiscal Policy (G) & 0.0248 & Stationer \\
\hline
\end{tabular}

Source: Processed by Eviews 9

\section{b. Lag Optimum Test}

The next step is to perform an optimal lag test. Selection of the optimal lag is very important, because it can affect the acceptance and rejection of the null hypothesis, result in estimation bias and can result in inaccurate predictions. The methods used are the likelihood ratio
(LR), Final Prediction Error (FPE), Akaike Information Criteria (AIC), Schwarz Information Criterion (SIC), and Hannan Quinn Information Criterion (HQ) with a minimum value. From table 2 it can be seen that the minimum value of all these criteria appears in lag 3 . Therefore, lag 3 is the optimal lag. 
Table 2. Lag Optimal Results

\begin{tabular}{ccccccc}
\hline Lag & LogL & LR & FPE & AIC & SC & HQ \\
\hline 0 & -448.0802 & NA & 680.1987 & 15.03601 & 15.14072 & 15.07697 \\
1 & -378.0126 & 130.7929 & 88.88847 & 13.00042 & $13.41929^{*}$ & $13.16426^{*}$ \\
2 & -365.5565 & 22.00576 & 79.42295 & 12.88522 & 13.61824 & 13.17194 \\
3 & -354.7220 & $18.05744^{*}$ & $75.17758^{*}$ & $12.82407 *$ & 13.87124 & 13.23367 \\
4 & -350.0864 & 7.262553 & 87.95712 & 12.96955 & 14.33087 & 13.50203 \\
5 & -344.1748 & 8.670238 & 99.33463 & 13.07249 & 14.74797 & 13.72786 \\
6 & -334.6499 & 13.01735 & 100.3831 & 13.05500 & 15.04463 & 13.83325 \\
7 & -326.0813 & 10.85357 & 105.9689 & 13.06938 & 15.37316 & 13.97051 \\
8 & -321.7827 & 5.015103 & 130.8913 & 13.22609 & 15.84402 & 14.25011 \\
9 & -312.1123 & 10.31507 & 137.6776 & 13.20374 & 16.13583 & 14.35064 \\
10 & -305.0350 & 6.841386 & 161.5627 & 13.26783 & 16.51407 & 14.53761 \\
\hline
\end{tabular}

Source: Processed by Eviews 9

\section{c. Stability Test}

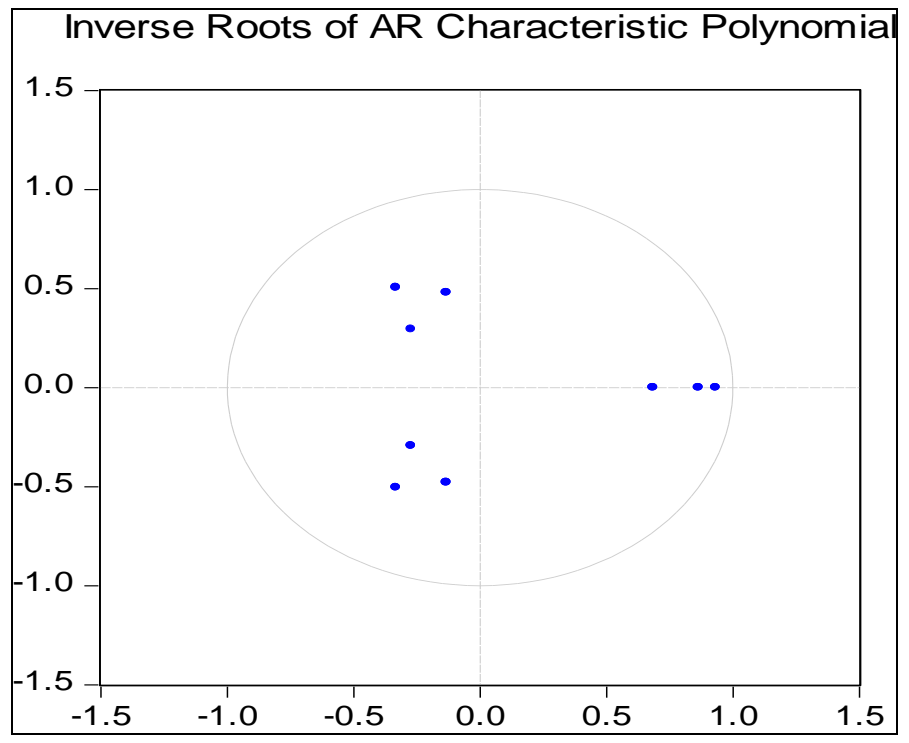

Figure 1. AR Roots Modulus Value

After the optimal lag test is continued by performing the VAR stability test. This test is valid for the IRF and Variance Decomposition results. VAR stability is seen from the inverse roots of the AR polynomial characteristics. If all the AR-roots values are in a circle, then the VAR system can be said to be stable and vice versa. Figure 1 shows all the nominal AR modulus values contained within the circle. Thus, it can be said that, the VAR system in this model is stable. A stable VAR will produce a valid IRF and Variance Decomposition.

\section{d. Cointegration Test}

Next step is to test the cointegration. This test is to find out, whether there will be balance in the long term. If the model is integrated, the model is analyzed using the VECM method, but if the model is not integrated, the model is analyzed using VAR. In table 3, it can be seen that the 
three variables in this equation have a small probability value of 0.05 , meaning that the variables do not occur cointegration, therefore the model used is the VAR level method.

Table 3. Cointegration Test

\begin{tabular}{lcccc}
\hline $\begin{array}{c}\text { Hypothesized } \\
\text { No. of CE(s) }\end{array}$ & Eigenvalue & $\begin{array}{c}\text { Trace } \\
\text { Statistic }\end{array}$ & $\begin{array}{c}0.05 \\
\text { Critical Value }\end{array}$ & Prob. $^{* *}$ \\
\hline None & 0.186302 & 28.10176 & 29.79707 & 0.0774 \\
At most 1 & 0.061555 & 9.546846 & 15.49471 & 0.3172 \\
At most 2 & 0.041653 & 3.829043 & 3.841466 & 0.0504 \\
\hline
\end{tabular}

Source: Processed by Eviews 9

\section{e. IRF Analysis}

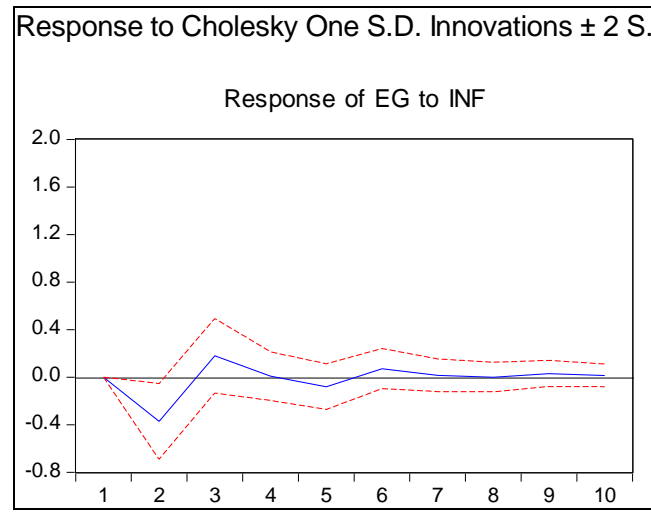

(A)

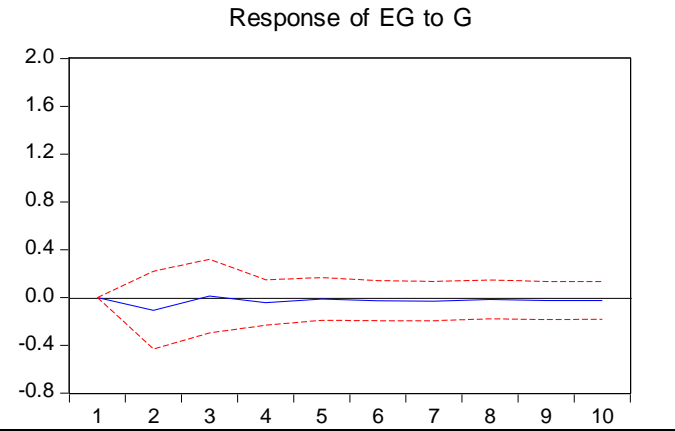

(B)

Figure 2. Economic Growth Response to Monetary (A) and Fiscal Policy's (B) Shocks

Furthermore, an Impulse Response Function (IRF) analysis is performed, which is used, to see the effect of shock on endogenous variables that will affect the variables themselves and will spread to other endogenous variables. IRF provides the direction of the relationship, the magnitude of the influence between endogenous variables. Estimates carried out for IRF, emphasize the response of a variable to changes in one standard deviation itself or other variables.

Figure 2A shows the response to changes in economic growth, due to shocks from monetary policy. The shocks at the First a the balance line, then deacreases to the second period, then increases in third period, then always remains on the balance line until the tenth period. Therefore, shocks from monetary policy to economic growth fluctuated until the fourth period, then continued to be on the balance line.

The condition almost same as shown in the response to economic growth from fiscal policy shocks, as seen in Figure 2B. Fiscal policy shocks initially decreased until the second period but not too far from the balance line, then the next period continued to be on the balance line, until the tenth period. Fiscal policy shocks do not have a permanent impact on economic growth.

\section{f. Contribution Test (Variance Decomposition)}

To see and analyze the effectiveness of monetary and fiscal policies on economic growth in ASEAN5 , it is seen from the value of Variance Decomposition. Table 4 shows that, in general the variability of economic growth, both in the short and long term, 
can be explained by shocks from monetary policy (other than itself) of $0.00 \%$ in the short term and $5.34 \%$ in the long term. the variability of economic growth in the short term is explained by fiscal policy shocks of $0.00 \%$, while in the long term it is $0.49 \%$. The conclusion from this result is that, the most effective policy for economic growth in ASEAN-5 by monetary policy. This can be seen from the largest contribution of monetary policy to the variability of economic growth compared to fiscal policy.

Table 4. Variance Decomposition Test Results

\begin{tabular}{ccccc}
\hline Period & S.E. & EG & INF & G \\
\hline 1 & 1.666740 & 100.0000 & 0.000000 & 0.000000 \\
2 & 1.713953 & 94.88214 & 4.724841 & 0.393022 \\
3 & 1.766610 & 94.14894 & 5.477419 & 0.373644 \\
4 & 1.816851 & 94.40979 & 5.180416 & 0.409795 \\
5 & 1.825190 & 94.26161 & 5.327519 & 0.410870 \\
6 & 1.838438 & 94.17353 & 5.399629 & 0.426844 \\
7 & 1.846069 & 94.18658 & 5.361848 & 0.451568 \\
8 & 1.849071 & 94.19749 & 5.344454 & 0.458055 \\
9 & 1.852508 & 94.17234 & 5.351102 & 0.476561 \\
10 & 1.854579 & 94.16027 & 5.345068 & 0.494658 \\
\hline
\end{tabular}

Source: Processed by Eviews 9

Monetary policy is more effective against economic growth in Asean-5, because the policy of increasing the money supply will increase aggregate demand, increase prices, and eventually increase output. In carrying out policies, the monetary authority is of course careful in price policy (inflation), because if prices are not controlled, it will certainly worsen the economy. This research is agree with Research from (Abata, Kehinde, \& Bolarinwa, 2012; Abdullahi \& Omeiza, 2019; Adefeso \& Mobolaji, 2010; Ajisafe \& Folorunso, 2002; Ali et al., 2008; Evans, Adeniji, Kelikume, \& Dakare, 2018; Hasan, Islam, Hasnat, \& Wadud, 2016; Havi \& Enu, 2014; Hsing, 2019; Idris, 2019; Jawaid, Arif, \& Naeemullah, 2011; Musa, 2013; Rahman, 2009; Rakić \& Rađenović, 2013; Şen \& Kaya, 2015; Takyi, 2017; Younus, 2016), which found that, Monetary policy is more effective than fiscal policy on economic growth.

Fiscal policy is seen as less effective in this study, it does not mean that fiscal policy in ASEAN-5 has not had any influence on economic growth, but the point is, the role of fiscal policies during the study period is less than monetary policy.

Given the irregular allocation of budget funds and non-productive expenditures by the fiscal authorities, the ineffectiveness of fiscal policy is not surprising. In addition, in an unstable market environment, the implementation of fiscal policy is highly determined and controlled by political forces.

Although the facts have proven that, monetary policy is more effective on economic growth in the five ASEAN countries, the use of appropriate fiscal policies, development spending which is more than non-development expenditure, can also improve economic indicators. If implemented properly, a careful combination of the two policies, can produce better results to boost economic growth. The results of this study found that, only maintaining effective and efficient monetary and fiscal policies can 
lead to sustainable economic growth (development).

\section{CONCLUSION}

The conclusion of this study is that, the monetary policy is more effective on economic growth in ASEAN-5, compared to fiscal policy. The effectiveness of monetary policy compared to fiscal policy can be seen from the contribution of monetary policy shocks to the variability of economic growth rather than fiscal policy. Fiscal policy is considered ineffective in this study, it does not mean that fiscal policy in ASEAN-5 has not had any influence on economic growth, but the point is, the role of fiscal policy during the study period is less than monetary policy. Given the irregular allocation of budget funds and nonproductive expenditures by the fiscal authorities, the ineffectiveness of fiscal policy is not surprising. In addition, in an unstable market environment, the implementation of fiscal policy is highly determined and controlled by political forces.

\section{REFERENCES}

Abata, M. A., Kehinde, J. S., \& Bolarinwa, S. A. (2012). Fiscal / Monetary Policy and Economic Growth in Nigeria: A Theoretical Exploration. International Journal of Academic Research in Economics and Management Sciences, 1(5), 75-88.

Abdullahi, A., \& Omeiza, M. (2019). Impact of Monetary Policy and Fiscal Policy on Economic Growth in Nigeria. Journal of Economics and Sustainable Development, 10(24), 145-154.

Adefeso, H. ., \& Mobolaji, H. I. (2010). The Fiscal-Monetary Policy and Economic Growth in Nigeria: Further Empirical Evidence. Pakistan Journal of Social Sciences, $\quad 7(2), \quad 137-142$. https://doi.org/10.3923/pjssci.2010.137 .142
Adegoriola, A. E. (2018). An Empirical Analysis of Effectiveness of Monetary and Fiscal Policy Instruments in Stabilizing Economy: Evidence from Nigeria. Social Sciences, 7(3), 133-140. https://doi.org/10.11648/j.ss.20180703. 14

Ajisafe, A., \& Folorunso, B. A. (2002). The relative effectiveness of fiscal and monetary policy in macroeconomic management in Nigeria. The African Economic and Business Review, 3(1), 23-40.

Ali, S., Irum, S., \& Ali, A. (2008). Whether Fiscal Stance or Monetary Policy is Effective for Economic Growth in Case of South Asian Countries? The Pakistan Development Review, 47(4), 791-799.

Arestis, P., \& Sawyer, M. (2004). Review of Social Economy On the Effectiveness of Monetary Policy and of Fiscal Policy. Review of Social Economy, LXII(4), 446-463. https://doi.org/10.1080/003467604200 0296218

Dahalan, J., \& Jayaraman, T. K. (2006). Monetary and fiscal policies in Fiji : a test of effectiveness. Pacific Economic Bulletin, 21(2), 94-102.

Evans, O., Adeniji, S., Kelikume, I., \& Dakare, O. (2018). The relative effect of monetary and fiscal policy on economic development in Africa: a GMM approach to the St. Louis equation The relative effect of monetary and fiscal policy on economic development in Africa: a GMM approach to the St . Louis equation. Business and Economic Quarterly, 2(0), 3-23.

Fatima, A., \& Iqbal, A. (2003). The Relative Effectiveness of Monetary and Fiscal Policies an Econometric Study. Pakistan Economic and Social Review, XLI(1 \& 2), 93-116. 
Hasan, M. A., Islam, M. A., Hasnat, M. A., \& Wadud, M. A. (2016). The Relative Effectiveness of Monetary and Fiscal Policies on Economic Growth in Bangladesh. Science Publishing Group, 5(1), $1-7$. https://doi.org/10.11648/j.eco.2016050 1.11

Havi, E. D. K., \& Enu, P. (2014). The Effect of Fiscal Policy and Monetary Policy on Ghana's Economic Growth: Which Policy Is More Potent? International Journal of Empirical Finance, 3(2), 6175 .

Hsing, Y. (2019). Is Expansionary Fiscal and Monetary Policy Effective in Australia? Journal of Business, Economics and Environmental Studies, 9(3), 5-9. https://doi.org/10.13106/jbees.2019.vol 9.no3.5

Idris, M. (2019). Relative Impact of Monetary and Fiscal Policy on Output Growth in a Small-open Economy. American Research Journal of Humanities \& Social Science (ARJHSS), 02(08), 2638.

Jawadi, F., Mallick, S. K., \& Sousa, R. M. (2015). Fiscal and monetary policies in the BRICs: A panel VAR approach. Economic Modelling, 1-8. https://doi.org/10.1016/j.econmod.201 5.06 .001

Jawaid, S. T., Arif, I., \& Naeemullah, S. M. (2011). Comparative analysis of monetary and fiscal Policy: a case study of Pakistan. Munich Personal RePEc Archive, (30850).

Musa, Y. (2013). Long and Short Run Relationship Analysis of Monetary and Fiscal Policy on Economic Growth in Nigeria : A VEC Model Approach Long and Short Run Relationship Analysis of Monetary and Fiscal Policy on
Economic Growth in Nigeria: A VEC Model Approach. Research Journal of Applied Sciences, Engineering and Technology, 5(10), 3044-3051. https://doi.org/10.19026/rjaset.5.4621

Musa, Y., Asare, B. K., \& Gulumbe, S. U. (2013). Effect of monetary-fiscal policies interaction on price and output growth in Nigeria. CBN Journal of Applied Statistics, 4(1), 55-74.

Rahman, M. H. (2009). Relative Effectiveness of Monetary and Fiscal Policies on Output Growth in Bangladesh : A VAR Approach. Bangladesh Journal of Political Economy, 22(1 \& 2), 420-440.

Rakić, B., \& Rađenović, T. (2013). The Effectiveness of Monetary and Fiscal Policy in Serbia. Industrija, 41(2), 103122.

https://doi.org/10.5937/industrija414011

Romer, D. (2011). Advanced Macroeconomics (4th ed.). New York: MCGraw-Hill.

Satrianto, A. (2017). Kebijakan Fiskal, Moneter dan Neraca Pembayaran di Indonesia: Suatu Kajian Efektifitas. Economac, 1(2), 54-64. https://doi.org/10.24036/20171241

Şen, H., \& Kaya, A. Y. (2015). The relative effectiveness of Monetary and Fiscal Policies on growth : what does long-run SVAR model tell us? Munich Personal RePEc Archive, O(0).

Tadesse, T., \& Melaku, T. (2019). Analysis of The Relative Impact of Monetary And Fiscal Policies on Economic Growth In Ethiopia, Using ARDL Approach to Co-Integration: Which Policy is More Potent? Copernican Journal of Finance \& Accounting, 8(2), 88-115.

Takyi, P. O. (2017). Do monetary, fiscal and trade policies matter for economic growth ?: Ghana's experience. Global 
Business and Economics Research Journal, 4(3), 1-16.

Tan, C., Mohamed, A., Habibullah, M. S., \& Chin, L. (2020). The Impacts of Monetary and Fiscal Policies on Economic Growth in Malaysia , Singapore and Thailand. South Asian Journal of Macroeconomics and Public
Finance, $1-17$. https://doi.org/10.1177/227797872090 6066

Younus, S. (2016). Relative Effectiveness of Monetary and Fiscal Policies on Output Growth in Bangladesh: A Co integration and Vector Error Correction Approach. 0-17. 